DOI: $\underline{10.20472 / T E .2017 .5 .1 .005}$

\title{
POLYTECHNIC EDUCATION TODAY AND THE DUAL SYSTEM
}

\author{
JIRI SEMRAD, MILAN SKRABAL
}

\begin{abstract}
:
This paper deals with the issue of polytechnic education as a highly topical issue at the current stage of the socio-economic transformation of society. In the diachronic approach, paying attention to the concept of education with regard to the current and future development of society, i.e. the information society, and knowledge society, this article focuses on the transformation of the concept of polytechnic education as a result of the industrialisation and digitalisation of society, the demands on the professionalization and intellectualization of the manufacturing processes. With regard to the problem of social development in cyberspace, this study further considers polytechnic and polymetic education in the context of the application of digital technologies and with respect to the application of the dual system of education. This article also deals with the issues of supporting the development of a positive relationship to technology, taking into account the terms of readiness of the young generation for productive activities with the support of the creative relationship to reality.
\end{abstract}

\section{Keywords:}

Polytechnic education; polymetic education; industrialization of society; professionalization and intellectualisation of the manufacturing processes, education, and training; socio-economic transformation of society; information society and knowledge society; critical thinking; educational goals; concept of education; dual system.

\section{Authors:}

JIRI SEMRAD, Czech technical university of Prague, Masaryk institute of advanced studies, Czech Republic, Email: jiri.semrad@cvut.cz

MILAN SKRABAL, Czech technical university of Prague, Masaryk institute of advanced studies, Czech Republic, Email: milan.skrabal@cvut.cz

\section{Citation:}

JIRI SEMRAD, MILAN SKRABAL (2017). Polytechnic education today and the dual system. International Journal of Teaching and Education, Vol. V(1), pp. 54-66., 10.20472/TE.2017.5.1.005 


\section{INTRODUCTION}

In the past, the question of polytechnic education was occasionally given all too much attention under the banner of bringing closer together education and practice, and life in general. Given the fact that we find ourselves in the era of science, information, and digital technologies, the question arises whether polytechnic education can still be seen as a valid pedagogical problem. The aim of the study presented is to describe the development of the opinions on polytechnic education in its historical context, pointing out its role in the present day, particularly in relation to the use of digital technologies and also with regard to the issues currently monitored possibilities and conditions for the application of dual systems of education.

\section{The Evolution of Polytechnic Education}

The question of polytechnic education is closely connected to the problem of updating the relationship between general and vocational education. Although a specific form of polytechnic education, a form shaped by the given historical period as well as by the development of crafts, trade and a newly self-asserting social class, can be found in the works of J. A. Comenius during the late Renaissance, the phenomenon aggressively asserted its importance towards the end of the 19th century in connection with the growing industrialisation (S. Hessen, 1936). The earliest forms of polytechnic education can further be found in the works of J. Pestalozzi and the Philanthropist movement. The question of polytechnic education became even more acute after the First World War, in particular in relation to the reconstruction of national economies, but also in relation to the attempts to establish new economies in the USA and the former USSR (P. P. Blonskij, see Dýma, 1975). Any viable analysis of the work school as a concrete example of implementing the need for polytechnic education must further take into account the conception of Th. Litt (1958; see too F. Singule, 1992) who identifies experiencing, direct living-through, and the expression of real life as the characteristic features of the work school. The ideas of our predecessors concerning the definition of the term polytechnic education, ranging from the inclusion of handicraft activities to the transfer of class instruction to manufacturing facilities, stand much removed from our recent position.

The question of polytechnic education grew in importance in the first half of the 20th century, emerged as a crucial problem in the second half of the 20th century, and became a highly topical problem at the turn of the 20th century, that is, at the time of what has been described as a post-industrial, information society, and/or learning society (Liessmann, 2008), or a knowledge-based society, especially in connection with the increasing number of scientific discoveries and the development of sciences, the close focus on so-called economic growth, the transformation of labour (digital technologies), and a new structuring of society.

As mentioned above, the question of polytechnic education asserted itself hand in hand with the industrialisation of society. The development of machine production led to profound changes not only in the organisation of society but also in its spiritual life. 
These changes were reflected in the educational process as a result of external pressures which industrial magnates put on the definition educational aims, as well as on the concept of education in general. A tendency towards conforming education as a whole to the needs of industry and business appeared in American pedagogy at the turn of the 19th century; the same tendencies can be observed slightly later in postrevolution Russia. The result of this tendency was that vocational training was seen as more valuable than general education. Requirements related to the process of industrialisation imposed on the educational process were increasing alongside the increasing division of labour and rationalisation of the manufacturing process. This in turn led to the implementation of specialised education which aimed at developing the predispositions of a child for integration into the manufacturing process at the earliest age possible. However, the decision making process about children's integration into the manufacturing process did not take into consideration their individuality.

As stated above, the crystallisation of polytechnic education in the first half of the 20th century in the then superpowers, i.e. USA and USSR, displays analogical tendencies. This was given first of all by the fact that the pragmatic pedagogy developed in the USA by scholars such as J. Dewey appealed to the foremost Soviet theorists led by N. K. Krupska (Semrád, 1989), P. P. Blonskij and others, who enabled the transformation of some of the pragmatic ideas and their integration into the newly emerging soviet educational conception. Consequently, Blonskij's book The Work School' (1919) had a decisive influence on the post-revolutionary reform of the Russian and Soviet system of education (Dýma, 1975), in which Blonskij himself took an active part. Blonskij dissociated himself from the conception of the work school based on craft manualism which was put into practice by Kerschensteiner in Germany (see Dýma, 1975), replacing manualism with machine production, craft with industrialisation, and professionalism with multipurpose polytechnicism. Craftwork was accepted only as one of the stages of work education, a stage which would precede the direct engagement of children and youngsters in the productive work for society. In order to make the children as influenced by the process of industrialization of society as possible, the work education took place directly in factories where it was possible to meet the crucial requirement of polytechnism by integrating the students into the body of producers. The students could thereby be in continuous contact with the manufacturing process as well as with factory life. The lessons utilised factory machines as well as factory training methods. Later stages of the Russian and Soviet pedagogical theory interpreted excessive industrialisation and technicisation of the manufacturing process critically, and saw it as narrowly conceptualised polytechnism which ignored the general fundaments of science and technology. The basis of the Russian and Soviet polytechnic education was then formed by the concept of the so-called complexes, that is, certain types of projects which were dealt with not only on the theoretical level.

\footnotetext{
${ }^{1}$ Some sources translate Blonskij's book Трудовая школа (1919) as The Labour School, this study translates its title more accurately as The Work School.
} 
Similar ideas were held by a number of German pedagogues of the in the 1920s and 1930s, for example by S. Kaweran and P. Oestereich who preferred the so-called production school (Dýma, 1975; Pařízek, 1977) and understood it as an organisational element in the economic, cultural and social life of adults. P. Oestereich pleads for the integration of the production school into the economic process of society, and for the eventual synthesis of the pedagogical and economic approaches. According to these authors, the polytechnic education represents an ideal and optimal type of education in terms of the degree of interconnectedness between education and economy. According to this approach, production becomes the foundation of human culture; true labour production then becomes the centre of the educational effort. The questions connected with the concept of polytechnic education are thereby articulated on the level of creativity, although in the given concept of production, this represents only its elementary layer.

The idea of a productive school in Germany, but other countries back in the 90 s of the last century, though other reasons are purely economic nature. It solves the issue of having enough skilled workers in technical fields and services. They talk about the socalled dual education system, which is intended to reduce youth unemployment. Theoretical training takes place in state and public educational institutions and provide practical training, including economically, businesses. The basic feature of the dual system is that the student has a dual status - at the school has a pupil position, and at the company has concluded a contract of employment. Without polytechnic education, however, this system cannot do, because it assumes that students have a deeper relationship mastery of the technique, not only at the user level. This assumes recovery polytechnic education in the full breadth of that term in primary and lower secondary education (Pícl, 2014; MŠMT\&NúV, 2015).

Polytechnic education has become more topical in relation to the mass dissemination of digital technologies, their impact on human personality and social relations, but also in connection with the growing professionalization and intellectualisation of manufacturing processes, and the widening gap between humans and their physical environment. The digitalisation of society has further changed the traditional conception of industrial production. Traditional producers and working men have become lab technicians, specialised workers, assistants and employees in the sense of white-collar workers. Digitalisation influences socialisation and has thereby introduced a new dimension into social relationships precisely because these relationships can exist primarily as facilitated by digital technologies. On the other hand, digital technologies seem to provide more space for creativity; however, in reality, digital technologies in fact also limit and hinder creativity. Furthermore, this process sidelines physical and mental pre-dispositions for manual skills which in the past constituted the foundation of the ethnographic, folkloristic, and cultural heritage of a given society.

As stated above, the question of polytechnic education is, from the historical perspective, closely related to the discussion of general and vocational education. For example, as J. Skalková (2009) points out, after the culmination of the conflict between 
general and vocational education generated by the unparalleled scientific and technological progress in the 20th century, as well as by the use of modern technologies in everyday lives, an entirely new phase in the development of the relationship between these two types of education has taken place, a phase in which some features of these two types of education come closer to each other, some undergo a change in the function of their content (general becomes vocational and vice versa).

As part of the process of modernisation of the educational content, polytechnic education has become an important factor in dealing with the complex relationship between general and vocational education. Starting in the 1970s, UNESCO has recommended the integration of the subject matter of technological nature into educational content (Skalková, 2009). However, this recommendation was not something entirely new because even the so-called socialist education, under the influence of pragmatic pedagogy, which took the reality of our everyday lives as its starting point, articulated the need for work education which encompassed not only the acquisition of technological foundations, but also the creation of a positive attitude towards work (Blonskij, 1928). Polytechnic education was meant to be implemented in close relation to the general learning content in mathematics and the natural sciences. The purpose of polytechnic education was not only to help students to become familiar with the use of various tools and pieces of equipment, and the development of practical skills, but also to become acquainted with the world of labour, learn how to cooperate, and professionally solve problems resulting from working with the latest technologies and new scientific discoveries. All these activities took place within the context of increasing the effectiveness of the national economy and of the socio-economic transformation of the society.

In addition, the first decades of the 21st century have introduced the need to develop various new concepts of thinking. This need results from the impact of digital technologies which have enabled a previously unimaginable accumulation of vast amounts of information, but at the same time have lead to a situation in which this information is mistaken for knowledge. Further, since at the beginning of the 21st century, knowledge became more and more specialised as a result of increasing specialisation in individual areas of scientific, technological, and economic development, it has become apparent that the future of knowledge lies with the synthesis of thought processes. In addition, the gap between practical and intellectual aspects of life is dangerously widening. Given this situation, polytechnic education should, besides other things, contribute to bridging these gaps, for example the gap between technology-oriented thought and the social sciences. As B. Suchodolský added, the higher one's vocational education, the deeper should one's general education be. With this being said, it comes as no surprise that the natural sciences today use some of the methodological approaches and methods borrowed from the social sciences (Schwanitz, 2013); as Schwanitz puts it: "At this very moment, the gap between the natural sciences and the humanities seems to be slowly closing because notions such as reflection and self-referentiality, which until recently existed exclusively 
in the humanities, more and more often determine the problems of natural sciences" (2013).

\section{Polytechnic and Polymetic Education}

Polytechnic education offers not only a systematic "step into" the world of technology, but also the incorporation of students' experience into the process systematic knowledge acquisition. One's own experience is very powerful as a motivating factor, but also as a basis for further learning, precisely because it is very concrete. As a result of this, one's experience also has its limits, and young learners need more systematic and compact knowledge, which is brought to him or her through education in the sciences and technology, but also in art, using his or her own experience. Polytechnic education allows students to learn the practical use of acquired scientific and technical knowledge in the context of socio-economic conditions. Work education should become a polytechnic educational subject which would affect aims focused on acquiring the fundamentals of both manual work and digital technologies. The terms "general", "vocational", and "polytechnic" education primarily reflect the extent of education, the concept of educational content, but also express different levels of knowledge of the world. All types of general education should at the same time be polytechnic. A crucial constituent which helps in meeting the requirement of a personality harmonically developed towards polytechnic education in the 21 st century is the so-called polymetic education, as defined by O. Chlup in one of his last studies in 1962 (see Pařízek, 1977). After more than 50 years, the opinions of $O$. Chlup from the 1960s that foresee future development of society in cyberspace seem quite visionary.

The advent of digital technologies is often discussed in relation to the so-called 'second culture' (Schwanitz, 2013). A number of western theoreticians claim that the society is overtly technicised and lacks humanistic dimension. In relation to digital technologies, it is possible to observe a transformation of the nature of interpersonal relationships, in particular in relation to their realization.

One of the most important sociologists, F. Webster, describes an information society as a gateway to a knowledge society (2006, p. 8 - 9), and introduces six (Webster originally talks about five, only to add the last and most important definition) characteristic definitions of the information society: technological, economic, occupational, spatial, cultural, and finally, theoretical knowledge. The emphasis Webster places on theoretical knowledge is extraordinary. As K. Kolesárová Saková (2016) points out, Webster's point of view might be compared to that of R. Richta (1969) who, in his book Civilizace na rozcestí (Civilisation at a Crossroads, Richta, 1969), claimed that education in a post-industrial society attains a new quality, and knowledge generates new added value. From the perspective of pedagogy, this means the increase in the importance of general education and its methodological dimension, as well as a transformation of the relationship between general and vocational education. A similar position is also proposed by R. B. Reich (2002), who draws on the work of D. Bell. According to his position, the typical features of an information society understood as a gateway into a 
knowledge society are the three following occupational categories: common production services, personal services, symbolic and analytical services.

The last of the tree categories is ascribed the least importance from the perspective of future development. This category is currently fulfilled 15 percent whereas it should be the crucial category in future. According to Reich, the mission of this category is to conceptualise tasks and their solutions. In order to achieve this, one must be equipped with abstract as well as critical thinking, the ability to synthesise, experiment, work together and cooperate, the ability to look beyond data, construct meanings and not merely accept them the way it is done in today's schools.

Nevertheless, given their unique nature, digital technologies in a certain sense link physical and mental work. It is O. Chlup who in the 1960s complains about the failing attempts to link physical and mental work into a unified "mutually adherent, labour, intellectual, ethical and emotional-educational whole" (see Pařízek, 1997, p. 195). O. Chlup hailed the fact that applied cybernetics had entered the educational process but at the same time he was acutely aware that all machines used in the process of learning, and digital technologies used during instruction can significantly influence essential aspects that play a role in the acquisition of subject matter by the mechanisms of memory. In this context, $\mathrm{O}$. Chlup spoke of neo-behaviouralism asserting itself in the educational process as a mere reproduction of memorised pieces of knowledge. Polymetic education should therefore represent the means by which it is possible to overcome the deformations of not only polytechnic but also of general education. $\mathrm{O}$. Chlup was also well aware of the fact that the admission of cybernetics into education could strengthen the role of competitive, achievement-based education at the expense of socially oriented education.

O. Chlup sees polymetic education as the second aspect of an activity, be it a physical or a mental activity. The term has its origin in the Greek word "metis", which means wisdom, reason, ingenuity, or thinking. It is expected that polymetic education is accomplished by a productive activity, that is, by various types of creative work. Acquired facts and sub-data represent a mere pre-requisite for further processing based on inner ideas about the acquired phenomenon as well as on the use of different types thinking, including dialectic or relational thinking. Polymetic education represents the a synthesis of knowledge which is a result of deep deliberation on the subject matter, deliberation that is based on inner experiencing, feeling oneself as part of the value of the acquired piece knowledge, enriched by the personality of each individual. O. Chlup thereby considers not only the theoretical heritage of cultural pedagogy, but also anticipates reflective knowledge as it is used by D. Schwanitz (2013, p. 513). Polytechnic education emphasises the necessity for children to develop the ability to think, and for teaching the young generation how to use different types of thinking that would allow them to mould the information provided by digital technologies into real knowledge. Polymetic education at the same time presupposes work with cultural heritage; industrial heritage thus becomes an indispensable part thereof. 


\section{Polytechnic Education Today}

Concerning the development of thinking in relation to digital technologies, emphasis is first of all placed on critical thinking, which should always go hand in hand with computer literacy. Critical thinking is globally considered as one of the most important educational goals. It is listed among skills which every young person in the 21st century should have. The attention paid to this phenomenon stems first of all from the role digital technologies play in the life of the young generation. A number of teachers and educators argue that the lives of the young generation are primarily consumed through digital technologies that often do not convey objective, true information, but give space to gossip, hoaxes, ungrounded information, etc. The ability to control digital technologies should be accompanied by the ability to critically asses acquired information in order to transform it into a creative, socially acceptable product.

Critical thinking is described by a number of specialists. The problem with the majority of these definitions is that they fail to capture the essence of critical thinking and typically limit themselves to defining the concept by describing only some of its aspects. The study presented relies on the following definition of P. Tittle (2011, p. 5): "Critical thinking is judgemental. It's thinking carefully about something in order to evaluate it and ultimately decide whether or not it's something you should accept. So critical thinking is a how-not-to-be-gullible kind of thing." A similar definition is provided by R. Ennis who claims that critical thinking is: "reasonable decision-making about what might and what might not be believed" (Johnson 1985).

As part of defining and developing the concept of critical thinking, critical interpretations appear that see it more as a form of lifestyle rather than a matter of education that might be learned (Švarcová, 2010). For these reasons, critical thinking is sometimes seen as affiliated with upbringing rather than education. Given the fact that a number of theorists actually link critical thinking with creative activities, the connection between critical thinking and a creative attitude towards reality comes to mind. This notion designates an attitude framework which presupposes the application of a creative response in all situations, irrespective of the outcome. A creative attitude towards reality is therefore underpinned by the desire to achieve something, to stir the "still waters", not to imitate and not to copy other solutions (Semrád, In. Hlavsa a kol., 1981).

On the other hand, a large number of studies and practically-oriented approaches towards education reduce critical thinking to reading and writing skills, that is, to prevailingly cognitive aspects of the young learner's individuality. An example of this attitude might be seen in a magazine and an internet portal "Kritické listy" that focuses on facilitating the experience to teachers; similar attitude acquires an RWCT program, which is also presented via this portal, called "Čtením a psaním ke kritickému myšleni" (Reading and Writing towards Critical Thinking; see http://www.kritickemysleni.cz/infosit.php). In line with the arguments presented above, the programme website (http://www.kriticke mysleni.cz/oprogramu.php) presents a list 
of methods that include: mind-mapping, brainstorming, free writing, pair discussion, learning from each other, spider web discussion.

Most of the studies that deal with the problem of critical thinking enumerate elements that constitute the basis of critical thinking or describe what skills an individual has to have in order to be able to think critically (www.criticathinking.org). From the educational point of view, these questions are not formulated in an ideal way because they are very difficult to operationalize. Moreover, the lists presented are very often formulated from an adult perspective. Defining education that should lead towards critical thinking one should, in our opinion, first of all become aware of moments that may hinder the application of critical thinking and focus all attention on overcoming these impediments.

One of the crucial barriers can be the world-view of a given person and the values that are connected to it, as we see for example with fundamentalist movements or individuals. World view is a key category for every individual and their life since it expresses the position from which they relate themselves to the surrounding world, its perception and evaluation, or a position from which they enter into the world. Naturally, the starting point of critical thinking is problem resolution. With this being said, the crucial barrier might be whether I actually do want to solve these problems, whether I am not a fatalist, or simply so indolent that I prefer going with the flow. All of these questions are questions concerning one's world-view.

From the perspective of education, it is also important to ask when or at what age should a child be allowed to use digital technologies. For instance, a number of theorists from the field of architecture point at the growing number of extremely similar buildings and argue that the reason behind this trend is the fact that future construction engineers and architects simply use various kinds of software that automatically draw pieces of design which in the past had to be laboriously drawn up by architects themselves with the help of tools such as the French curve. In this respect, one should carefully discuss which of the stages of the educational process is ideal for the introduction of architectural software into the class so that the creativity, imagination, and fantasy of the students are not impeded.

In order not to become a critique for its own sake, critical thinking must grow from deep erudition supported by the cultural legacy of the past (Schwanitz, 2013; Eco, 2008). As for example Schwanitz puts it, the essence of erudition inheres within the knowledge of this cultural legacy. Critical thinking of course cannot succeed without the fundamental principles of logical thinking, but at the same time must be nurtured by other types of thinking, for example by connective and relational thinking. Its basis naturally rests with the dialectical thinking developed by Plato, Comenius, Hegel and others (Floss, 1974). Relational thinking has its social and emotional dimension that cannot be ignored. For example, as R. Honzák (Šimůnková, 2016) points out, there is a place in the human brain where emotions and reason meet. Honzák further points out that intelligence alone is not the most important thing, the more important of the two is emotional 
intelligence because the human world does not rest on the laws of cause and effect but on relationships.

A creative attitude towards reality in particular requires adequate development of emotions, because intuitive thinking, which stands behind the greatest discoveries, relies on emotional intelligence as well as on deep experiences and enjoyment. Experiential education, should it fulfil its function, cannot be reduced to adrenalinoriented physical education; it must cover a much wider spectrum and facilitate the cultural legacy, for example the aforementioned industrial heritage. As the international experience suggests, critical thinking can be best developed in so-called team learning (Chandrasekaran et al., 2016) that allows students to acquire competencies such as being an outstanding communicator, competent critic and manager (Manzione et al., 2016) by working on given projects.

\section{CONCLUSION}

Summing up the presented data, it is possible to conclude that polytechnic education represents a highly topical problem, though only on condition that it meets certain given criteria. Polytechnic education should therefore be understood as a part of general education, and as such should contribute to the development of young students in the unity of the physical, psychical, manual, and spiritual aspects. Polytechnic education should further contribute to establishing a positive attitude towards technology, but also lead to the correct understanding of when technology represents the means and when it represents the ends in people's lives. With respect to the over-technicised society, polytechnic education can be successful only when developed in harmony with that form of polytechnic education which expands and cultivates the thinking of young students by utilising different forms or styles of thinking, including critical thinking, but also by facilitating the link between young students and the cultural and technical heritage. Polytechnic education should be accomplished with a productive activity underpinned by a creative attitude towards reality and creative effort. Renewed interest in polytechnic education in the 21st century is clear from the application needs of the dual system in vocational education. The condition for the successful operation of the dual system as a tool for addressing reduction of youth unemployment, the consistent application of polytechnic education in primary and lower secondary education. This application is a prerequisite for the formation of the desired relationship of young people to technology, not only in the user plane.

\section{REFERENCES}

BLONSKIJ, P. P. a RUFIN, I. I., ed. P.P. Blonskij v jego pedagogičeskich vyskazyvanijach: S avtobiografijej P.P. Blonskogo "Kak ja stal pedagogom i imenno takim kakim ja stal". Moskva: Rabotnik prosveščenija, 1928. 116 s. Pedagogičesk. dejateli v ich vyskazyvanijach / Pod red. I.M. Deomidova i A.P. Pinkeviča. 
BLONSKIJ, P. P. Trudovaja škola (The Labour School/The Work School). Trudovaja škola vtoroj stepeni. Učitel' trudovoj školy. Moskva: Gos. izdat., 1919. Serija po teorii i praktike jedinoj trudovoj školy.

DRIGAS, A. et al. ICTs based Physics Learning. International Journal of Engineering Pedagogy. No: 3 , 2016. ISSN: 2192-4880

DÝMA, M. P. P. Blonskij: z jeho života a díla (P. P. Blonskij: his life and work). Praha: Státní pedagogické nakladatelství, 1975. 194 s. Z dějin pedagogiky.

ECO, U. Poznámky na krabičkách od sirek (Notes on boxes of matches). Praha: Argo, 2008. $471 \mathrm{~s}$. ISBN 978-80-7203-929-6.

FLOSS, P. Komenský a Platón (Comenius and Plato). Studia Comeniana et historica. Roč. 4, č.8/9 (1974) ISSN 0323-2220.

HESSEN (GESSEN) S. I. a PATOČKA, J. Filosofické základy pedagogiky (Philosophical Foundations of Education). Praha: Československá grafická unie a.s., 1936.

HLAVSA, J. ed. a kol. Psychologické problémy výchovy $k$ tvor̆ivosti (Psychological problems of education for creativity). Praha: SPN, 1981. Knižnice psychologické literatury.

CHANDRASEKARAN, S.; AL-AMERI, R. Assessing Team Learning Practices in Project/Design Based Learning Approach. International Journal of Engineering Pedagogy. No: 3, 2016. ISSN: 21924880 .

JERETIN-KOPF, M.; WUTTKE, C. Ch.; HAAS, R. \& WIESMÜLLER, Ch. Methods and Tools for Enabling Employees to Contribute to Technological Progress. International Journal of Engineering Pedagogy. No: 3, 2016. ISSN: 2192-4880.

JOHNSON, R. H. Some Observations about Teaching Critical Thinking. CT News, Critical Thinking Project. Sacremento: California State University, 1985, roč. 4, č. 1, str. 5-6.

KOLESÁROVÁ, K. Životní styl $v$ informační společnosti (Lifestyle in the Information Society). Praha: Univerzita Jana Amose Komenského, 2016. ISBN 978-80-7452-119-5.

KOMENSKÝ, J. A. Vybrané spisy (Selected writings). Praha: Státní pedagogické nakladatelství, 1969.

LIESSMANN, K. P. Teorie nevzdělanosti: omyly společnosti vědění (Theory of illiteracy: errors knowledge society). Praha: Academia, 2008. XXI. století; sv. 4. ISBN 978-80-200-1677-5.

LITT, Th. Das Bildungsideal der deutschen Klassik und die moderne Arbeitswelt (The educational ideal of German classical music and the modern working world). Bonn: Bundeszentrale für Heimatdienst, 1958. $148 \mathrm{~s}$.

MANZIONE, L. et all. Preparing Engineering Students for the Global Sourcing Environment. International Journal of Engineering Pedagogy. No: 3, 2016. ISSN: 2192-4880.

MARTINCOVÁ, Jana. Úroveň kritického myšlení studentů vybrané fakulty humanitních studií: Level of Critical Thinking of Students of Selected Faculty of Humanities. Lifelong learning = Celoživotní vzdělávání. Brno: Mendelova univerzita v Brně, Institut celoživotního vzdělávání, 2016, 6(2), 83105. ISSN 1804-526x. 
MŠMT \& NÚV. Analýza systémů odborného vzdělávání v Evropě a ve světě (Analysis of vocational training systems in Europe and the World). Praha: Ministerstvo školství, mládeže a tělovýchovy and Národní ústav pro vzdělávání, 2015. [online]. Dostupné na: http://www.nuv.cz/uploads/POSPOLU/Studie_dualni_systemy_FIN.pdf

PAŘíZEK, V. ed. Otokar Chlup a perspektivy výchovy (Otokar Chlup and perspectives of education). Praha: Státní pedagogické nakladatelství, 1977. 217 s. Z dějin pedagogiky.

PÍCL, M., ČERNÝ, J. a GARGULÁK, K. Duální systém odborného vzdělávání jako řešení potřeb trhu práce $v$ ČR (The dual system of vocational education as a solution to the needs of the labor market in the Czech Republic). Praha: Odbor analýz a informací Úřadu vlády České republiky, 2015. 70 stran. ISBN 978-80-7440-133-6.

REICH, R. B. Dílo národů: príprava na kapitalismus 21. století (The Work of Nations: Preparing for the 21st Century Capitalism). Překlad Miloš Calda. V českém jazyce vyd. 2. Praha: Prostor, 2002. ISBN 80-7260-064-8.

RICHTA, R. et al. Civilizace na rozcestí: společenské a lidské souvislosti vědeckotechnické revoluce (Civilization at the crossroads: social and human context of the scientific revolution). 3. rozš. vyd. Praha: Svoboda, 1969.

SEMRÁD, J. Tvořivost v systému výchovy N. K. Krupské (Creativity in the educational system N. K. Krupskaya). Pedagogika, 4/1989. ISSN 0031-3815.

SCHWANITZ, D. Vzdělanost jako živý dialog s minulostí: vše, co musíte vědět, chcete-li rozumět prítomnosti (Education as a lively dialogue with the past: everything you need to know to understand the presence of). Překlad D. Petříčková a M. Petříček. V českém jazyce vyd. 2. Praha: Prostor, 2013. Obzor; sv. 83. ISBN 978-80-7260-273-5.

SINGULE, F. Současné pedagogické směry: a jejich psychologické souvislosti (Current educational guidelines: and their psychological implications). Praha: Státní pedagogické nakladatelství, 1992. 55 s. ISBN 80-04-26160-4.

SKALKOVÁ, J. Společenskovědní poznání v sitích inženýrského vzdělávání (Social networks of knowledge in engineering education). Brno: Paido, 2009. 85 s. ISBN 978-80-7315-173-7.

ŠIMŮNKOVÁ, T. Psychiatr Radkin Honzák o LSD, IQ, důvěře a dinosaurech (Psychiatrist Radkin Honzák of LSD, IQ, trust and dinosaurs). Právo: nezávislé noviny. Přiloha Salon, 22. 9. 2016, s. 3. Praha: BORGIS, 2016. Dostupné na: https://www.novinky.cz/kultura/salon/415500-neilarmstrong-a-jini-psychopati-psychiatr-radkin-honzak-o-Isd-iq-duvere-a-dinosaurech.html

ŠVARCOVÁ, E. 2010. The Role of Critical Thinking for Well-being of Individual and Society. JindřichůV Hradec 8. 9. 2010 - 10. 9. 2010. In: IDIMT-2010. Linz : Trauner Druck GmbH\&Co KG, 2010. ISBN 978-3-85499-760.

ŠVARCOVÁ, E. Výchova ke kritickému myšlení (Education for Critical Thinking). Praha: VŠE, 2010. Dostupné z: http://kdem.vse.cz/resources/relik10/PDFucastnici/Svarcova.pdf

TITTLE, P. Critical thinking: an appeal to reason. New York: Routledge, 2011. ISBN 978-0-415-997140. 
WEBSTER, F. Theories of the information society. 3rd ed. London: Routledge, 2006. ISBN 0-41540633-1. 